\title{
Augustine Confessions and the Impossibility of Confessing God
}

\author{
Rev. Robert M. Vallee, Ph.D. \\ St. John Vianney College Seminary
}

This work attempts to understand why the work of Augustine of Hippo has experienced such a widespread revival in postmodernity, especially in the writings of Jacques Derrida. At first glance, an alliance between a postmodern atheist and a fourth century bishop and saint seems an unlikely one. However, it is not so strange if one considers that Augustine deals extensively with the problems of sin and guilt. The residue of his guilt survives even the grace of his conversion. The connection between Augustine and the postmoderns is, perhaps, found in the common experience of guilt. The postmoderns are plagued by guilt without the consolation of absolution: guilt for the excesses of modernity, guilt for the rape of the environment, guilt for the holocaust, guilt for surviving when so many others did not. This work contends that Augustine's thought and Derrida's thought are, both, enriched by this odd, but fruitful, play of interpretations. This chapter attempts to situate Augustine in a postmodern context. It will focus primarily on Augustine's text but read that text from a postmodern perspective.

Augustine has experienced many revivals in the history of the West. But perhaps none so surprising as the current engagement with postmodernity. Moreover: “Augustine has played an interesting role in postmodernism. Not only does he appear in Derrida's Circumfession and Memoirs of the Blind, but Lyotard, too, was working on the Confessions at the time of his death, and Heidegger's early lectures on St. Augustine have just been published in the Gesamtausgabe." It will perhaps be through the revival of the Augustinian tradition of the restless heart that Catholicism will be able to engage in a real dialogue with postmodernity.

Augustine's thought is resurrected and relevant again. The thinker at the birth of the medieval experiment is recalled to the center of discourse, albeit after a 1500 year hiatus. Nevertheless, 
1500 years of dust cover little rust. How to think thoughtfully? It would appear the answer is-along with Augustine-in tears, by a deep humility, with an awareness of the sheer phenomenality of the terms of thought, with a sigh and a groan, with a confession, a confession of sin, guilt, finitude and how terribly thoughtless our thought tends to be.

How might a postmodern thinker approach the central problem of language? Perhaps in manner similar to that of Augustine. Augustine's Confessions takes up the problem of language from the very beginning: "What has anyone achieved in words when he speaks about you? Yet woe to those who are silent about you because, though loquacious with verbosity, they have nothing to say."- Augustine broaches the strange possibility of an impossible speaking. On the one hand, speaking can do no good (quid dicit aliquis, cum de te dicit?). On the other hand, it is the greatest of all tragedies if we dare not to speak (et vae tacentibus de te, quoniam loquaces muti sunt). We are impaled, mute and blabbering, on the horns of a dilemma. If we speak, we are foolish. If we dare not to speak, woe to us. As Derrida holds, "something becomes possible as impossible.,"3

For Augustine, God, the fullness of presence, is never fully present. Language flounders in the dark and fecund depths of this aporia. Yet, this floundering is the precise condition of the possibility of speech. If not Augustine then, perhaps, no other writer in the history of the West has had so great an awareness of the paucity of the written word. "Written" is an important qualifier. Of course, Socrates and, perhaps, Jesus Christ himself, recognized the inferior status of thought and language in comparison to truth. However, neither Socrates nor Jesus was a writer. It is extraordinary that Augustine rivals their caution, while all the while writing. Writers, for their part, tend to idolize their words. Augustine, for all of the glittering beauty of his words, ever resists idolatry in all its forms, logolatry and verbolatry in particular. The admonition of Genesis could use a bit of clarifying: "You shall have no strange gods before me, and remember, all gods are strange."

Augustine is clear as to his inability to name the ineffable, is clear as to how deeply strange his relationship with his God is. In one of the most poignant passages of his Confessions, he writes, 
"What am I to you, Lord, that you should command me to love you, and that, if I fail to love you, you are angry with me and threaten me with vast miseries? If I do not love you, is that but a little misery...Speak to me so that I may hear. See the ears of my heart are open before you, Lord. Open them and say to my soul, 'I am your salvation.' After that utterance I will run and lay hold on you. Do not hide your face from me, lest I die. Let me die so that I may see it."4 Herein, Augustine proposes a theory of language and hermeneutics of meaning which is not often employed in Western thought. He speaks of the "ears of his heart" (ecce aures cordis $m e i$ ). This heart without repose (cor irrequietum) is the foundation of Augustine's theology and spirituality. However, it is also at the center of his epistemology. As Gabriel Marcel commented in his attempt to understand disquiet in the thought of Augustine, "this heart is not separated from the thought which genuinely constitutes man as such."' Augustine would have no strange gods before God, not even a god of his own invention, not even an idol crafted in the subtle creativity of his own mind: You shall have no strange Gods before me, and remember, all gods are strange, especially the ones we dream up for ourselves.

There is a complex theory of language, a highly sophisticated hermeneutic of meaning which runs through the whole of the Confessions, indeed throughout the whole of Augustine's theology. However, it is within the context of the Confessions that this hermeneutical tension is most evident. It is as though Augustine vacillates between two extremes: I cannot speak; I must speak; I cannot speak; I must speak; and so on, in an infinite play of impossible speech. Speech is twisted and tortured so as to discover that which is beyond all discovery. Language presumes to present the unpresentable. Augustine specifies: "If anyone finds your simultaneity beyond his understanding, it is not for me to explain it. Let him be content to say 'What is this?' (Exod. 116: 15). So too let him rejoice and delight in finding you who are beyond all discovery rather than failing to find you by supposing you to be discoverable."

The word is not heard due to the fact that one supposes that one might actually, and exhaustively, hear it. Augustine sets forth an odd, yet immensely fruitful, puzzle of language. The very 
meaning to be gained in speech is lost in the presumption of speaking. Discovery is barred at the precise moment when discovery is presumed to be possible. The possible meaning is only possible as impossible. Further on, Augustine will ask: "Who understands his sins?"7 He might just as well have asked, who understands his words? Or, who understands the speech by which one asks: who understands...?

The matter of central importance for Augustine clarifies itself with his implied criticism of Cicero, "whose language (but not his heart) almost everyone admires." "The "but not his heart" phrase should follow the Latin, pectus non ita, and be relieved of parentheses. There is no less parenthetical phrase in all of Augustine's writings. Augustine, despite being one of the most gifted writers in the history of the West, perceives that a fluid style is useless if one has nothing to say. Moreover, the something of speech is not a matter of mental gymnastics, cleverness or wit. The something to say flows from the heart. Cicero does not lack talent, native intelligence or a felicitous capacity for expression. Cicero lacks the contents of the heart. Cicero wrote/spoke beautifully, prettily convincingly and, most of all, vapidly.

The tender and exquisite conclusion to Book III presents an example of Monica speaking an impossible word. Monica goes to a bishop to ask him to debate with Augustine and turn him from the error of his ways. The bishop declines, claiming that Augustine is unready for repentance. Monica, with the persistence and shamelessness of a mother, will not take no for an answer: "She pressed him with more begging and floods of tears, asking him to see me and debate with me. He was irritated and a little vexed and said: 'Go away from me: as you live, it cannot be that the son of so many tears should perish." Monica presses the bishop with begging and floods of tears-hardly a rational argument but an argument nonetheless. The bishop is not moved by her logical arguments. Rather, the bishop is moved by her tears. Moreover, the bishop does not respond with a rational, or even psychological, argument. Instead, he offers an extraordinary confession of faith: "It cannot be that the son of so many tears should perish." These words are understood by Monica the way that one understands music-in an immediate mediation to her heart. ${ }^{10}$ It is impossible to 
separate the content of what is being given in this heavenly presence from its manner of being given. Hence, "she had taken these words as if they had sounded from heaven." "I

Monica speaks and then receives a word in a new and subtle language, the language of the heart. She speaks, if such a thing is possible (or at least possible as impossible), a word of tears. Heaven replies, if such a thing is possibly impossible, with an inaudible word of comfort, not spoken (dicit) but sounded (sonuisset) from heaven. Monica hears a sounding and not a speaking.

This sounding as opposed to speaking is of crucial importance. With the sounding, Monica grasps an ineffable meaning, a meaning which cannot quite be distilled into words. It is a meaning which can be talked about and around but never directly addressed, never distilled. As Socrates said of the fear of death, "You must sing incantations over it every day until you charm the bogy away."12 Again, it is the analogy of music which may shed some light upon this impossible speaking. In a certain sense, the entirety of the Confessions is a sung incantation. Augustine sings over his sins and, once charmed, his song gives rise to thought.

Augustine is a son of many tears. Even in sin, he wandered, "being seduced and seducing, being deceived and deceiving, in a variety of desires." 13 The wetness of his tears and his mother's tears, certainly drench his confessional biography. Those tears, likewise, soak the substance of Augustine's thought in general. Clearly, it remains to be seen if Augustinian tears fall anywhere but in the Confessions. Nevertheless, it is the contention of this interpretation that City of God, De Trinitatae and The Teacher obey the hermeutical logic of tears instigated in the Confessions. Augustine's sins meander, "in a variety of desires." In a similar fashion, his thought meanders in desire, albeit a desire for the e.rstasis of the Divine otherness.

The death of Augustine's unnamed friend in Chapter IV is a crucial hinge-moment in the development of the tearful logic of the Confessions. With this death, Augustine becomes a vast problem to himself, "I became a vast question to myself, and my soul interrogated itself" (factus eram ipse mihi magna quaestio, et interrogabum animam meam). ${ }^{\text {It }}$ I become a vast question to myself. No more philosophical words than these have ever been writ- 
ten. Nevertheless, what sort of question turns the subject into a vast question mark? The question of myself, and the questioning of myself, illuminates and obscures. Moreover, as is music, the question of the purely erotic (érotique pure), gives way to the ecstasy of belief.

As for Augustine, the self-scrutinizing question mark of grief produced little in the way of theoretical or practical answers. Thus: "Only tears were sweet to me, and in my soul's delight, weeping had replaced my friend." 15 Tears do not merely serve to console Augustine and their value far exceeds their psychologically purgative effects. Rather, tears take the place of his friend (amico meo) as the dearest delight of the soul (deliciis animi mei). The value of tears is not limited to the psychological or moral realms. Tears bear ontological weight and must be throughly investigated.

The philosopher is obligated to determine the difference between the contents of that which is presented and the manner of being present, while all the while realizing that these two can never be completely separated. The manner of being present carries one into the region of the heart. Weeping, in a manner of speaking, recreates the world and broadens the possibility of what the world might mean for the weeper: "Man is a vast deep, whose hairs, Lord, you have numbered, and in you none can be lost. Yet, it is easier to count his hairs than the passions and emotions of his heart." 16 The topography of the human heart is complex. The movements of the heart open a vast field of questions, aporias and hermeneutical tensions. Nevertheless, no mystery is more mysterious than the soul awakening. The soul is a vast deep and is only explicable as inexplicable.

For Augustine, clarity and precision are low-order virtues; they are important but only in reference to relatively unimportant matters. Certainly, clarity and precision shed little light on the soul. For example, Aristotle's book on the categories impressed Augustine as being "an extremely clear statement about substances."17 This clarity gave birth to a deeper and darker confusion: "What help was it to me when this book was also an obstacle? Thinking that absolutely everything that exists is comprehended under the ten categories, I tried to conceive you also, my God, wonderfully simple and immutable, as if you too were a subject of which beauty 
and magnitude are attributes." 18 The clarity of the Categories obviates its original purpose. In the end, the book is not a light to illumine the way but an obstacle in the path. To employ a distinctively Augustinian analogy, this ultra-clear rationality turns upon itself like a dog upon its master ("et latrare adversum te"), ${ }^{19}$ literally that is, I "barked" against Thee.

The start of Book V hints at an interesting possibility. Augustine writes: "Your entire creation never ceases to praise you and is never silent. Every spirit continually praises you with mouth turned towards you; animals and physical matter find a voice through those who contemplate you. So from weariness our soul rises towards you, first supporting itself on the created order and then passing on to you yourself who wonderfully made it."ㄱ) There are two crucial matters at stake in this brief quote. As usual, Augustine, a profound interpreter of texts, needs careful interpretation.

First, he claims that, "animals and physical matter find a voice." How could animals, much less physical matter, find a voice? What speaking is spoken by animals, brutish by definition? Moreover, how might it be possible that inanimate and opaque matter finds a voice? Doubtless, such a dual miracle is mediated through "those who contemplate them." Nevertheless, we who speak are able to give voice to the mute and make sense of the prosaic meaninglessness of the pure given. The human being speaks, and impossibly speaks, for the less than human. Hence, the human is revealed as more than human. Augustine dreams the dream of the unspeakable, the ineffable, the impossible. He does so by the tortured logic of confession. He speaks for the less human by the same illogical logic whereby he speaks of his sin, his guilt and his tears.

Second, "the weariness of our soul rises toward you." The inability to speak is a manner of speaking. Obviously, one must take care not to attribute too through-going a Platonism to Augustine. Still more absurd would be to claim that Augustine is, tout simple, a neo-Platonist after the fashion of Plotinus, insofar as, the created order passes over to the Creator. The physical order cannot explain itself by immanent causality. Instead, the metaphysical order makes sense of the physical order. This is, doubtless, true for Augustine. However, it would seem that postmodernity undertakes a similar tack in its critique of modernity. 
It is not style, this or that manner of speaking, which determines truth: "Wisdom and foolishness are like food that is nourishing or useless. Whether the words are ornate or not does not decide the issue."21 Faustus, who so greatly disappoints Augustine's high hopes, is not utterly disappointing. At the least, he is not one of "those many loquacious people," whom Augustine had to endure, who attempted to teach him while having nothing to say. Yet, the difference between Faustus and these unnamed prattlers has nothing to do with erudition, wit or method. Instead, Faustus is better, if only slightly better, because: "He had a heart which, if not right towards you, was at least very cautious with himself."22 Truth is fashioned in the heart.

Here, the alliance with postmodernity is evident: "Picking up a phrase from Saint Augustine, Derrida says that truth in deconstruction has to do with doing or making truth (facere veritatem), making truth happen, effecting it, forming and forging truth."23 Reality is not deconstructed in deconstruction. Rather, the fable world of constructed method is deconstructed so as to allow the undeconstructible to impossibly present itself. However, this undeconstructible is not utterly obscure, even if it is not precisely on the order of scientific or rational knowledge. The trace of meaning in Augustine's tears is "heterogeneous to the formalizable order of knowledge." 24

It is always shocking to realize that Augustine lived in the fourth and fifth, and not the seventeenth, century. There are passages which one could well imagine to have come from Descartes: "I wanted to be as certain about things I could not see as I am certain that seven and three are ten." 25 In a sense, Augustine is already postmodern before the outbreak of modernity. He confronts the problem of certainty in knowledge and moves toward faith rather than criticism. Hence, if not actually postmodern, he is at least post critical. He does not go around, but through, the critical question.

Once confronted with the problem of certitude, Augustine undergoes a gradual conversion, which is as much epistemological as it spiritual: 
Then, little by little, Lord, with a gentle and merciful hand you touched and calmed my heart. I considered the innumerable things I believed which I had not seen, events which occurred when I was not present, such as many incidents in the history of nations, many facts concerning places and cities which I have never seen, many things accepted on the word of friends, many from physicians, many from other people. Unless we believed what we were told, we would do nothing at all in this life. Finally, I realized how unmoveably sure I was about the identity of my parents from whom I came, which I could not know unless I believed what I heard. ${ }^{26}$

It dawns on Augustine that even the simplest and most self-evident data of ordinary knowledge would be rendered inaccessible if forced to live up to the rigid and impossible criteria of certainty. The difference between Augustine and his modern counterparts is that he deems it counter-intuitive and absurd to conclude that "I cannot know if the sun will rise tomorrow." Belief, therefore, is not set against knowledge. To the contrary, belief is the precise condition of the possibility of knowledge. The fault lays not with belief but with unbelief, in that, unbelief cannot even sustain itself in a meaningful way. The unbeliever, should he be radical and constant in his unbelief is, at best, reduced to silence. At worst, the unbeliever subverts his own truths in a circular movement of epistemic suicide.

The quest for certitude is ultimately self-defeating on many levels, the most evident of which is the psychological level. Certitude is a brand of intellectual neurosis. The lust for certitude must be set aside so that the mind can engage in the free play which is constitutive of thought itself. Extreme anxiety, even anxiety as to the justifications of thinking, petrifies thought. Truth is something like a relaxation, a fluidity of human faculties in a perpetual play: "When are we to recreate ourselves and unbend our minds, allowing the mind to relax from the tensions of anxieties?"27 
The progress of uneasiness and anxiety resolving themselves in faith is manifest in Augustine. Gabriel Marcel makes the claim, "joy whatever one might think of it, does not exclude uneasiness such as we have seen it in particular define itself for St. Augustine." ${ }^{28}$ Uneasiness is the aspiration of the minus being (moinsêtre) for the plus being (plus-être). Augustine's thirst is ultimately quenched. However, one must take care not to travel too quickly through these middle Books of the Confessions, since one cannot appreciate the quenching unless one feels the thirst. Indeed, philosophical interpretations of The Confessions tend to jump immediately to books ten and eleven, on memory and time respectively. While one could argue that from a philosophical perspective these are crucial books, one might also argue that they are incomprehensible without the nine books of searching which precede them.

Augustine repeatedly shows himself to be unafraid of the openness of aporias. In Book VII, he writes: "I was seeking the origin of evil and there was no solution."29 Even while Augustine's intellect wallows in a quagmire of vanity and presumption, his heart was turning rightly toward truth: "As in silence I vigorously pursued my quest, inarticulate sufferings of my heart [soul] were loudly pleading for your mercy." "310 God's mercy must not be interpreted too narrowly. Truth is no less of a mercy than justice or compassion.

There is a side issue which must be addressed. The Confessions are not addressed to the reader. They are addressed to God. In a certain sense, the reader of Augustine engages in an act of spiritual voyeurism. Peter Brown states it perfectly: "Augustine's back is turned to us throughout the Confessions. His attention is elsewhere. He is speaking with his God. The pronoun $t u$ - "Thou," "You"-occurs in 381 of the 453 paragraphs of the Confessions." 31 Yet Augustine writes: "And now I confess to you, O Lord, in writing (Et munc confiteor tibi, domine, in litteris)." 32 The question must arise: for whom is Augustine writing? Surely not for God, who knows the secrets of Augustine's heart better than Augustine himself knows them.

Augustine's writing has a metaphysical and transcendent function. Which is to say, he writes to express the inexpressible in rags of sick expression. Writing presents the unpresentable: "When I 
write there is nothing other than what I write. Whatever else I felt I have not been able to say, and whatever else has escaped me are ideas or a stolen verb which I will destroy, to replace them with something else." 33 The writing is not for God. The writing is for Augustine himself that he might dredge forth from darkness the secrets of his soul.

Writing, especially Augustine's writing, combines monstrous pride with saintly humility. He writes to say what cannot be said. So, why write? Because it cannot be said. But if it cannot be said, why write? Do we not thus risk idolatry? Not if one knows that it cannot be said. The speakable reveals itself as unspeakable. Therefore, "whatever way you turn, you have not even started thinking." "3t The act of confession never quite rises to the level of thought; confession is simultaneously demure and audacious-but never so audacious as thought itself: "Readers can feel they have stumbled, unawares, on the most intimate of scenes-a human being (themselves as much as Augustine) brought with joy and trembling into the presence of God, their judge and their friend." 35 This is a way of speaking, though perhaps not a way of thinking critically, about God.

Finally, the question of certainty resolves itself for Augustine, albeit in a rather non-traditional manner: "You have mercy on dust and ashes, and it has pleased you to restore my deformities in your sight. By inward goads your stirred me to make me find it unendurable until, through my inward perception, you were a certainty to me." 36 Some qualifications need to be made with regard to the translation of "through my inward perception, you were a certainty to me." As seen above, this translation, emphasizing certainty as it does, is perhaps too simple and does not capture the subtlety of the Latin text. Augustine's text reads: "donec mihi per interiorem aspectus certus esses." A more literal translation would read: "until such time as it might be assured to my inward sight, that it was thou thyself." In spite of the awkwardness of the English prose, the literal sense must be retained. It is not certainty which is at stake but an "assurance unto my inward sight." Augustine, as mentioned above, is not seeking the sort of clarity from the invisible things that he seeks from the visible things; such clarity is illusory in any event. Augustine seeks, instead, to rest on a deeper 
assurance, an assurance rooted in his relationship to the God who is beyond all understanding. This God could never be a certainty in the sense of being as certain to the intellect as the fact that $7+3=10$. God is not produced, deduced or found at the end of a syllogism. Rather God is the conceptual framework that makes all syllogisms, propositions and deductions possible. In short God is not a truth but the conceptual hasis of all possible truth.

The start of Book VIII presents the most unpresentable passage of the Confessions: "My desire was not to be more certain of you but to be more stable in you." ${ }^{37}$ Epistemologically, Augustine gives us a prayer of, and for, truth. Truth is not a thing of which I am certain. Truth is that non-thing of which $1 \mathrm{am}$. I am not, ever or truly, certain of truth. I am, if such state of being is possible, assured in truth. The desire for truth is as much desired as it is acquired. Truth has every bit as much to do with what I am as with what I have. I stand before truth. I stand within truth. I am because there is truth and can speak of truth because I am.

It is necessary to interject a note of caution into these reflections, lest one attempt a wildly anachronistic work, something like Augustine as a postmodern Writer. Augustine is not a postmodern writer. However, the apophatic elements of his theology are consequential for postmodern thought: "Thus while it would be comical to find a negative theology in deconstruction, it would not be surprising to find deconstruction in negative theology-as a practice, as a strategy, as a way negative theologians have found to hold the claims of cataphatic theology at bay." 38

Truth, so contends Augustine, is more a matter of stability in than certainty about. This contention holds true throughout the Confessions. Moreover, the notion of truth as an assurance pervades the whole of Augustine's theology. Truth is not something grasped, something comprehended. Instead, truth grasps and comprehends us. As Augustine wrote in the Contra Faustus, "to know the truth we must live in the truth." Why? Simply put, because the truth is bigger than we are. We dwell in truth. The truth does not dwell in us.

There is a Zen story of four pygmies who went off into the dark jungle to seek the elephant God. In the darkest night, they find the elephant but it is so pitch black that they cannot see. They 
each touch the god in the darkness. Upon returning to their village, they are asked what the god was like. The first says, "he is like a wall." He touched the side of the elephant. The second says, "he is like a hose." He touched the nose of the elephant, The third said, "he is like a rope." He touched the tail. The fourth said, "he is like a tree." He grabbed he leg. The story ends with the question: which of the pygmies was right? Of course, they are all right insofar as they are able to grasp this thing that is so much bigger than themselves. This story, aside from its theological and ecumenical value, has epistemological implications. Truth is not something we produce. Instead, in a certain manner of speaking, we are productions of truth. Truth haloes us and prods us to attain a deeper ontological depth. By living in the truth, one's horizon is expanded and made more fecund. We grow in the truth; the truth does not grow in us. Like pygmies blindly grappling with the elephant god, we never exhaust, or even fully grasp, the object of our knowing.

Therefore, the art of knowing is a perpetual and fully human struggle to dwell in truth. The rational or logical mode is only one way, among many ways, of knowing. Further, rationality grievously errs if it seeks to establish itself as the only mode of knowing. Rational discourse finds its impetus in a non-rational foundation and ultimately falls back exhausted on that foundation: "The arguments were exhausted and had all been refuted. The only thing left was a mute trembling, and, as if it were facing death it was terrified of being restrained from the treadmill of habit by which it suffered 'sickness unto death." 39 This mute trembling does not end in death. Instead, it gives way to the actual moment of conversion for Augustine. Trembling gives way to barely tempered truth. With Alypius in the garden at Milan, Augustine finally gives in to the ineluctable pull of conversion. Augustine goes off by himself and within him is, "precipitated a vast storm bearing a massive downpour of tears...I threw myself down somehow on a certain figtree, and let my tears flow freely. Rivers streamed from my eyes." +10 The all-important hinge moment of conversion is accomplished not with an argument or a syllogism, but by a dissolution into tears. Moreover, reminiscent of Monica's hearing a wordless message sounded from heaven, Augustine suddenly hears "a voice from a nearby house, chanting as if it might be a boy or a girl (I 
don't know which)."'4l The fact that the conversion is accomplished is testified to by Augustine. Yet, the conversion is accomplished with groans, sighs and tears. Augustine has remade the world through weeping. The warm, wet intimacy of his tears has accomplished what Cicero, Aristotle, Neo-Platonism and Manicheaism could not. Augustine has finally found the key to his heart, the secret and occult meaning of his desires. In a sense, the first paragraph of the Confessions is revealed in its true and fullest sense: "You stir man to take pleasure in praising you, because you have made us for yourself, and our heart is restless until it rests in you."12 Truth is not, can never be, a cold and detached truth. Augustine, could be read as an anticipatory corrective to Modernity. We are not detached spectators and reason cannot purify itself to such a degree that it accepts nothing as true except that which appears as clear and distinct to the mind. Perspective is not rarified and detached. Rather, perspective, as always, is already full. ${ }^{43}$

Book Ten is, in many ways, the highwater mark of the Confessions. The truth is explicitly bound together with Augustine's remembering and sighs and tears: "As to the other pleasures of life, regret at their loss should be in inverse proportion to the extent to which one weeps for them. The less we weep for them, the more we ought to be weeping." +4 Augustine being so deeply literary and yet cautious as to the adequacy of the written word, stands as the first great remedy to the problem of Western logocentricism.

Augustine writes, and tears drown his writing in a seemingly endless play of impossible speech: "This I desire to do, in my heart before you in confession, and before many witnesses with my pen." 45 Here is a fascinating play of language and thought. The aim of Augustine's writing is to lay bear his heart in confessions. However, he will do this "with his pen before many witnesses." Hence, "What could be hidden within me, even if I were unwilling to confess it to you? I would be hiding you from myself, not myself from you. Now, however, my groaning is witness that I am displeased with myself." 46 Augustine writes and does not write: "Therefore my God, my confession is made both in silence and not in silence. It is silent in that there is not audible sound; but in love it cries aloud." 47 Again, the eternal play of impossible significations arises: silent and not silent, spoken and unspoken, present 
and absent. Augustine's writing is a signifier of the signifier which, "conceals and erases itself in its own production." +48

A disclaimer or a waming is offered the reader of The Confessions: "I also, Lord, so make my confessions to you that I may be heard by people to whom I cannot prove that my confession is true. But those whose ears are opened by love believe me." 49 It is not proof which is at issue but assurance. As with all matters of great subtlety or depth, certainty is no ontological guarantee. Truth is stirred up in the soul by love. To know truth, one must love truth.

This notion, as to the "loveableness" of truth, becomes much more clear when one considers Augustine's approach to the ultimate truth: "Yet there is a light I love, and a food, and a kind of embrace when I love my God-a light, voice, odor, food, embrace of my inner man, where my soul is floodlit by light which space cannot contain, where there is sound that time cannot seize, where there is perfume which no breeze disperses, where there is a taste for food that no amount of eating can lessen, and where there is a bond of union that no satiety can part. That is what I love when I love my God." 50 Augustine speaks of a longing that is unbroken by satiety, a desire for that which is unpresentable, ungraspable and ineffable. No signifier is able to establish a reference to a signified. Yet, for all that, the signifier continuously attempts to refer to that which is beyond all reference; the attempt to speak the unspeakable establishes itself at the root of all language.

What miraculous and trespassing sign is able to effect the process of inner embrace of which Augustine speaks? One would need to find some way to understand what is meant by a "light that space cannot contain and a sound that time cannot seize." However such a grasping must be possible insofar as, "human beings can put a question to the invisible things of God." 51

Memory is the key term here in Book Ten. It unlocks all mysteries, for all is contained in the vast treasure house of memory. Yet, what is remembered is remembered at a level more foundational than the merely verbal level. Logos, for all of its exaggerated priority of place thus far in the Western tradition, is given its first disciplinary session here in Augustine: "With my tongue silent and my throat making no sound, I can sing what I wish."\$2 
There is no limit to the power of memory in Augustine. It is vast and infinitely profound. The hegemony of logos is here re-ordered and disciplined in Augustine's epistemology.

Actually, the source of logos' discoursivity is to be found in the brooding, silent, wordless presence of memory. The mind's encounter with the treasure store of memory is not creative on the part of the mind. The mind does not produce what it thinks. Instead: "By thinking we, as it were, gather together ideas which the memory contains in a dispersed and disordered way, and by concentrating our attention we arrange them in order as if ready to hand, stored in the very memory where previously they lay hidden, scattered, and neglected." 53 Hence, the mind is not productive, much less purely creative. The mind serves a purely regulative and ancillary function, and thought is in the service of memory.

The contents of thought need to be gathered (cogenda) so as to be known. They are collected from a dispersed state: "It is what is collected (that is, by force) in the mind, not elsewhere, which is strictly speaking the object of recollection." ${ }^{-4}$ The mind gathers by force, by a violence. Further, this violent gathering passes over much of what it would gather up: "Metaphysical illusion consists in treating a presentation like a situation...A presentation does not present a universe to someone; it is the event of its (inapprehensible) presence." 55 Augustine is no less aware of the danger of metaphysical illusion than is Kant. In fact, Augustine's fear of infidelity would render him even more loathe to transgress Divine mystery than Kant is loathe to allow the faculties to transgress one another's domain. For Kant, metaphysical illusion is only a mistake. For Augustine, metaphysical illusion would be idolatry.

The alliance of thought with idolatry is a subtle and ever-shifting one. Thought tends toward idolatry as a final and mortal temptation. There is a natural tendency to close off the aporia and so to strangle thought. Augustine the thinker resists this temptation with the shield of confession: "I at least, Lord, have difficulty at this point, and I find my own self hard to grasp. I have become for myself a soil which is a cause of difficulty and much sweat." 56 The exploration of the soul is a cause of much sweat and toil. Moreover, the image of the soil is not chosen capriciously. The soil is never all tilled. The soil is perpetually tilled anew. One can see a 
connection to the aforementioned slogan of Derrida: "To think is to re-think." One is never quite done with thinking. In fact, if one claims to be done, we can be sure of one thing at least, that one is no longer thinking.

The passage on forgetfulness is also relevant: "But what is nearer to me than myself? Indeed the power of my memory is something I do not understand when without it I cannot speak about myself. What shall I say when it is certain to me that I remember forgetfulness?"57 Augustine takes great delight in playing with many paradoxes which constitute thinking and speaking, if not thought and language. We remember forgetfulness. With memory, as later with time, Augustine knows what memory and time are until he is asked to explain. Then, he is unable to tell us. He knows and he does not know. Or, he knows until he reflects on it and then he no longer knows-an impossible speaking being spoken nonetheless:

What is time? Who can explain this easily and briefly? Who can comprehend this even in thought so as to articulate the answer in words? Yet what do we speak of, in our familiar everyday conversation, more than of time? We surely know what we mean when we speak of it. We also know what is meant when we hear someone else talking about it. What then is time? Provided that no one asks me, I know. If I want to explain it to an inquirer, I do not know. ${ }^{58}$

Augustine shows time and memory to be mysteries in the deepest sense of the word. He tells us that we cannot know them; then, he proceeds to spend the two longest and most difficult chapters of The Confessions writing about them, writing precisely about things of which he does not know. However, it is a speaking that remains always a speaking and never attains the level of speech. As Marcel would say, the mode of speaking in not so much a thought that is all thought out (pensee pensée) as it is a thinking thought (pensee pensante). This distinction corresponds roughly to what Bergson has termed an opened (pensee pensante), as opposed to a closed ( 
(pensee pensée)) manner of thinking. Augustine, first closes off the possibility of meaningful speech about God, then relentlessly and impossibly speaks. Augustine opens aporias and is comfortable with letting them remain open. Augustine is thinker who is quickly bored with problems and fascinated by mysteries, the mystery of himself and his world no less than the mystery of his God.

Ultimately, the object of thought is literally unthinkable. Even memory does not contain it, though the power of memory is precious and vast: "I will transcend even this my power which is called memory, so great is the force of life in a human being whose life is mortal. What then ought I to do, my God? You are my true life. I will transcend even this my power which is called memory. I will rise beyond it to move towards you who are constant above me." 59 Thought passes beyond the thinkable to what is constant above it. Thought, at the limit of its purview, dissolves, or passes, into reassurance (secura suavitas).

Toward the end of Book X, Augustine makes a startling and unimaginable demand. He writes: "See my condition! Weep with me and weep for me, you who have within yourself a concern for the good, the springs from which good action proceed."(6) So far, nothing too strange, merely a somewhat rhetorical flourish that begs the reader's sympathy. Then the other shoe drops: "You, Lord my God, hear, look and see and have mercy on me and heal me. In your eyes I have become a problem to myself, and that is my sickness." Recalling that the addressee of the Confessions is not the reader but God, Augustine is beseeching his God "to weep with him and for him." Augustine betrays a deep passion for the impossible. It is an impossibility that has its roots in the mystery of the human soul - I have become a problem to myself. Moreover, the impossibility stretches out to the border of the infinite-I invoke God, who has no eyes with which to weep, to weep for and with the dust he has made.

Kierkegaard, writing under the name of Johannes de Silentio, claimed, "everyone became great in proportion to his expectancy. One became great by expecting the possible, another by expecting the eternal; but he who expected the impossible became the greatest of all."62 It is clear that Augustine's passion for the impossible and the absolute carries him into the realm of the great. Derrida, in 
his fascinating study of his own/Augustine's religion entitled Circumfession, legislates: "Only write what is impossible, that ought to be the impossible rule."

Augustine situates his thought, his life and his confession before the Absolute, the selfsame, the Infinite and the Unspeakable. It is a passion, as Derrida holds, which is not alien to transgression. The bounds of the possible are continually transgressed, "which is what Derrida calls, following Blanchot, the passion of the pas, the pas of passion. What we have not understood is that deconstruction stirs with a passion for the impossible, passion de lieu, a passion for an impossible place, a passion to go precisely where you cannot go."'t

Now, the original questions should be readily answerable: what is the precise locus of Augustine's thought in postmodernity? Why are basically non-religious postmodern thinkers, such as Lyotard and Derrida, taking such an interest in Augustine, and especially in the Confessions? Clearly, the postmoderns have a passion for the impossible, for the unpresentable and for the silent margins of thought. Which idea is more impossible, more unpresentable, more unspeakable, more liable to be victimized by idolatry than the Augustinian idea of God? In fact, to even name God "an idea" is to fall under the sway of an implicit idolatry. Nothing is more unnameable than God. Yet, the act of naming the Divine is the core of what constitutes the human: I cannot speak; I must speak; I cannot speak; I must speak; and so on in an endless chain of reversals which constitute thought itself.

Finally, Augustine asks a question, a question that admits of no positive answer, "when shall I be capable of proclaiming by 'the tongue of my pen' all your exhortations and all your terrors and consolations and directives...? And if I have the capacity to proclaim this in an ordered narrative, yet the drops of time are too precious to me." petual deferral in the thought of Augustine. When will he exhaust the mystery of God? Clearly, never! Nevertheless, "the drops of time are precious to him." The question, the search for an answer which is perpetually unattainable, this questioning is itself precious and sacred. It is as though Augustine defers with a nearly Derridadean gesture. When? Not yet. When? Not yet. When? He 
told $u$ at the beginning. Our hearts were made for Yourself, $\mathrm{O}$ Lord, and they are restless-they will ever be restless-until they rest in You. Until that moment, the answer will always and ever be: "Not Yet!"

The postmoderns are fascinated with Augustine. Subsequent chapters will attempt to sort out why this is true for several particular thinkers. As a provisional answer, it seems that they are deeply interested in the Augustinian self, the confessing soul. The uncanny and mystical aspect of Augustine's thought is expressed in a deluge of tears, sighs and physical groans. The postmoderns are interested in a mode of thinking that does not fly away in abstraction but holds itself to account for the incarnation and embodiment. The quote from Gustave Thibon with which Gabriel Marcel ended a lecture at the Institut Supérieur de Pédagogie at Lyons on December 13th, 1942 serves well as a bridge from Augustine to postmodernity:

You feel hedged in; you dream of escape; but beware of mirages. Do not run or fly away in order to get free: rather dig in the narrow place which has been given you; you will find God there and everything. God does not float on your horizon, he sleeps in your substance. Vanity runs, love digs. If you fly away from yourself, your prison will run with you and you will close in because of the wind of your flight; if you go down deep into yourself all will disappear in paradise. ${ }^{.6}$

The Bishop of Hippo is as loathe as any postmodern to fly away in abstraction. The most persistent of all modern mirages is the empty and transcendental self. God does not float on the horizon, like some lovely metaphysical sunset, to be admired from afar. God sleeps in our substance. These words could be a direct on Augustine's Confessions. No thinker in the history of the West has been less other-worldly than Augustine, less prone to arid metaphysical speculation and disembodied abstraction. Little wonder that the postmoderns, who revolt against the angelism of modernity, would find an ally in Augustine. 


\section{Notes}

'John Caputo, "Postmodernism and the Catholic Tradition," American Catholic Philosophical Quarterly, Vol. LXXIII, 256.

${ }^{2}$ Augustine, Confessions, translated by Henry Chadwick, (Oxford: Oxford University Press, 1991), 5; cf., "aut quid dicit aliquis, cum de te dicit? Et vae tacentibus de te quoniam loquaces muti sunt" [Augustine, Confessions, (Cambridge: Harvard University Press, 1961), 8].

3 Jacques Derrida, Postmodernity and God II, Conference at Villanova, Oct 17, 1999.

4 Augustine, Confessions, 5; cf., "quid tibi sum ipse, ut amari te iubeas a me et, nisi faciam, irascaris mihi et mineris ingentes miserias? Parvane ipsa est, si non amen te?...sic dic, et audiam. Ecce aures cordis mei ante te, domine; aperi eas et dic animae meae: salus tua ego sum. Curram post vocem hanc et adprehendam te. Noli abscondere a me faciem tuam: moriar, ut eam videam" [Augustine, Confessions, 10].

${ }^{5}$ Gabriel Marcel, Problematic Man, translated by Brian Thompson, (New York: Herder and Herder, 1967), 99; cf., "ce crur n' est pas séparable de la pensée qui constitue véritablement l' homme en tant que tel" [Gabriel Marcel, L'Homme Problématique, (Paris: Présence de Gabriel Marcel, 1998), 122].

' Augustine, Confessions, 8; $c f .$, "quid ad me, si quis non intellegat? Gaudeat et ipse dicens: quid est hoc? Gaudeat etiam sic, et amet non inveniendo invenire, potius quam inveniendo non invenire te" [Augustine, Confessions, 18].

${ }^{7}$ Augustine, Confessions, 33; cf., "delicta quis intelligit?" [Augustine, Confessions, 92].

${ }^{8}$ Augustine, Confessions, 38-39; $c f$. ., "Ciceronis, cuius linguam fere omnes mirantur, pectus non ita" [Augustine, Confessions, 108].

${ }^{9}$ Augustine, Confessions, 51 ; $c f$., "atque illa nollet adquiescere, sed instaret magis deprecando et ubertim flendo, ut me viderat et mecum disereret, ille iam substomachans: 'vade' inquit 'a me; ita vivas, fieri non potest, ut filius istarum lacrimarum pereat' " [Augustine, Confessions, 142].

10 Marcel explains this possibility of musical communication: "L'être musical est une présence, et le premier soin du phénoménologue devra être de marquer l' impossibilité où nous sommes de dissocier effcetivement le contenu présent d' une part, le mode de présence, la façon d'être présent d'autre part" [Gabriel Marcel, L'esthétique musicale de Gabriel Marcel, (Paris: Aubier, 1980), 63]. 
1 Augustine, Confessions, 51 ; cf., "quod illa ita se accepisse inter conloquia sua mecum saepe recordabatur; ac si de caelo sonuisset" [Augustine, Confessions, 142].

12 Plato, Phaedo, translated by R. Hackforth, (Cambridge: Cambridge University Press, 1981), 78; $c f$. "Let the voice of the charmer be applied daily until you have charmed away the fear (of death)" [Plato, "The Phaedo," The Dialogues of Plato, translated by B. Jowett, (New York: Random House, 1920), vol. 1, p. 462].

${ }^{13}$ Augustine, Confessions, 52; $c f$., "seducebanur et seducebamus, falsi atque fallentes in variis cupiditatibus" [Augustine, Confessions, 146].

it Augustine, Confessions, 160.

15 Augustine, Confessions, 58; $c f$., "solus fletus erat dulcis mihi et successerat amico meo in deliciis animi mei" [Augustine, Confessions, 160].

${ }^{16}$ Augustine, Confessions, 66; cf., "grande profundum est ipse homo, cuilus etiam capillos $t u$, domine, numeratos habes et non minuuntur in te: et tamen capilli eius magis numerabiles quam affectus eius et motus cordis eius" [Augustine, Confessions, 186].

${ }_{17}$ Augustine, Confessions, 69; cf., "et satis aperte mihi videbantur loquentes de substantiis" [Augustine, Confessions, 196].

${ }^{18}$ Augustine, Confessions, 69; $c f$., "Quid hoc mihi proderat, quando et oberat, cum etiam te, deus meus, mirabiliter simplicem atque incommutabilem, illis decem praedicamentis putans quidquid esset omnino conprehensum, sic intellegere conarer, quasi et tu subiectum esses magnitudini tuae aut pulchritudini" [Augustine, Confessions, 198].

${ }_{19}$ Augustine, Confessions, 200.

21 Augustine, Confessions, 72; $c f$., "non cessat nec tacet laudes tuas universa creatura tua, nec spiritus omnis hominis per os conversum ad te; nec animalia nec corporalia per os considerantium ea, ut exsurgeat in te a lassitudine anima nostra, initens eis, quae fecisti, et adtransiens ad te, qui fecisti haec mirabiliter" [Augustine, Confessions, 206].

${ }^{21}$ Augustine, Confessions, 78; $c f$., "sed perinde esse sapientiam et stultitiam, sicut sumt cibi utiles et inutiles; verbis autem ornatis et inornatis" [Augustine, Confessions, 224].

22 Augustine, Confessions, 78; $c f$., "iste vero cor habebat, etsi non rectum ad te, nec tamen nimis incautum ad se ipsum" [Augustine, Confessions, 228].

${ }^{23}$ Jacques Derrida/John Caputo, Deconstruction in a Nutshell, (New York: Fordham, 1997, 166.

${ }^{24}$ Derrida/Caputo, Nutshell, 167.

${ }^{25}$ Augustine, Confesions, 95; cf., "volebam enim eorum quae non viderem ita me certum fieri, ut certus essem, quod septem et tria decem 
sint" [Augustine, Confessions, 278[.

${ }^{26}$ Augustine, Confessions, 95; $c f$., "diende paulatim tu, domine, manu mitissima et misericordissima pertractans et conponens cor meum, consideranti, quam innumerabilia crederam, quae non viderem neque cum gererentur affuissem: sicut tam multa in historia genbtium, tam multa de locis atque urbibus, quae no viderrem, tam multa amicis, tam multa medicis, tam multa hominibus aliis atque aliis, quae nisi crederentur; omnino in hac vita vita nihil aggeremus, postremo quam quam inconcusse fixum fide retinerem, de quibus parentibus ortus essem, quod scire non possem, nisi audiendo credidissem" [Augustine, Confessions, 282].

27 Translation mine; $c f$., "quando reparamus nos ipsos relaxando animo ab intentione curarum" [Augustine, Confessions, 312].

${ }^{28}$ Marcel, Problematic Man, 143; cf., "la joie, quoi qu'on en puisse penser, n' exclut pas l' inquiétude telle que nous l'avons vue en particulier se définir pour un saint Augustin" [Marcel, L'homme problématique, 187].

${ }^{29}$ Augustine, Confessions, 119; cf., "et quaerebam, unde malum, et non erat exitus' [Augustine, Confessions, 360].

30 Augustine, Confessions, 120; $c f$., "et cum in silentio fortiter quaererum, magnae voces erant ad misericordiam tham tacitae contritiones animi mei" [Augustine, Confessions, 360].

${ }^{31}$ Peter Brown, Introduction to an English translation of the Confessions, trans. F.J. Sheed, (Indianapolis: Hackett, 1970, xiii.

32 John Caputo, The Prayers and Tears of Jacques Derrida, (Bloomington: Indiana University Press, 1997), 295.

${ }^{33}$ Jacques Derrida, Writing and Difference, translated by Alan Bass, (Chicago: the University of Chicago Press, 1978), 169.

${ }^{34}$ Derrida, Writing and Difference, 169.

35 Brown, Introduction, xiii.

${ }^{36}$ Augustine, Confessions, 120-12; cf., "quoniam miseratus es terram et cinerem, et placuit in conspectu tuo reformare deformia mea. Et stimulis internis agitabas me, ut inpatiens essem, donec mihi per interiorem aspectus certus esses" [Augustine, Confessions, 364].

${ }^{37}$ Augustine, Confessions, 133; cf., "nec certior de te, sed stabilior in te esse cupiebam" [Augustine, Confessions, 402].

38 John Caputo, "Derrida and Meister Eckhart," Derrida and Deconstruction, edited by Hugh Silverman, (New York: Routeledge, 1989), 24.

${ }^{39}$ Augustine, Confessions, 146; $c f$. . "consumpta erant et convicta argumenta omnia: remanserat muta trepidatio, et quasi mortem formidabat restringi a fluxu consuetudinis, quo tabescebat in mortem" [Augustine, Confessions, 442]. 
*1" Augustine, Confessions, 152; cf., "oborta est procella ignens, ferens ingentem imbrem lacrimarum...ego sub quadum fici arbore stravi me nescio quomodo, et dimisi habenas lacrimas, et proruperunt flumina occulorum meum" [Augustine, Confessions, 462].

"Augustine, Confessions, 152; cf., "et ecce audio vocem de vicina domo cumcantu dicentis, et crebo repetentis, quasi pueri an puellae" [Augustine, Confessions, 462-464].

${ }^{42}$ Augustine, Confessions, 3.

${ }^{43}$ Ricoeur deals with this motion of perspective in: Paul Ricoeur, Fallible Man, translated by Charles A Kelbley, (New York: Fordham University Press, 1986), 17-24.

4 Augustine, Confessions, 179; $c f$. , "cetera vero vitae huius tanto minus flenda, quanto magis fletur; et tanto magis flenda, qunato minus fletur in eis" [Augistine, Confessions, II, 74].

${ }^{45}$ Augustine, Confessions, 179; $c f$., "volo eam facere in corde meo coram te in confessione, in stilto autem meo coram multis testibhus" [Augustine, Confessions II, 74].

t6 Augustine, Confessions, 179; cf., "quid occultum esset in me, etiamsi nollem confiteri tibi? Te enim mihi absconderem, non me tibi. Nunc autem quod gemitus meus testis est displicere me mihi" [Augustine, Confessions II, 74].

${ }^{47}$ Augustine, Confessions, 179; cf., "confessio itaque mea, deus meus, in conspectu tuo tibi tacite fit et non tacite. Tacet enim strepitu, clamat affectu." [Augustine, Confessions II, 76.

4* Derrida, Of Grammatology, 7.

49 Augustine, Confessions, 180; $c f$. , "dicit enim eis caritas, qua boni sunt, non metiri me de me confitentem, et ipsa in eis credit mihi" [Augustine, Confessions II, 80].

so Augustine, Confessions, 183; $c f$., "et tanem amo quandam lucem quendam vocem et quendam odorem et quendam cibum et quendam amplexum, cum amo deum meum, lucem, vocem, odorem, cibum, amplexum interoris hominis mei, ubi fulget animae meae, quod non capit locus, et ubi sonat, quod non rapit tempus, et ubi olet, quod non spargit flatus, et ubi sapit, quod non minuit edacitas, et ubi haeret, quod non dilvellit satietas. Hoc est quod amo, cum deum meum amo" [Augustine, Confessions II, 86-88].

s1 Augustine, Confessions, 184; cf., "homines autem possunt interogare, ut invisible dei per ea" [Augustine, Confessions II, 90.

${ }^{52}$ Augustine, Confessions, 186; $c f$., "et quiescente lingua ac silente gutture canto quantum volo" [Augustine, Confessions II, 96].

${ }^{53}$ Augustine, Confessions, 189; $c f$., "cogitando quasi colligere atque animadvertendo curare, ut tamquam ad manum posita in ipsa memoria, 
ubi sparsa prius et neglecta lattitabunt, iam familiari intentiononi facile occurrant" [Augustine, Confessions II, 104-106].

${ }^{54}$ Augustine, Confessions, 189; $c f$., "verum tamen sibi animus hoc verbum proprie vindicavit, ut non quod alibi, sed quod colligitur, id est cogitur, cogitari proprie iam dicatur" [Augustine, Confessions II, 107].

ss Jean-François Lyotard, The Differend, Phrases in Dispute, translated by Georges Van Den Abbeele, (Manchester: Manchester University Press, 1988), 61.

${ }^{56}$ Augustine, Confessions, 193; $c f$. ., "Ego certe, domine, laboro hic et laboro in me ipso: factus sum mihi terra difficultatis et sudoris nimii" [Augustine, Confessions II, 118].

57 Augustine, Confessions, 193; cf., "quid autem propinquius me ipso mihi? Et ecce memoriae meae vis non comprehenditur a me, cum ipsum me non dicam praeter illam. Quid enim dicturus sum, quando mihi certum est meminisse me oblivionem?" [Augustine, Confessions II, 118].

58 Augustine, Confessions, 230; cf., "quid est enim tempus? Quis hoc facile breviterque explicaverit? Quis hoc ad verbum de illo proferendum vel cogitatione comprehenderit? Quid autem familiarius et notius in loquendo comemoramus quam tempus? Et intellegimus utique, cum id loquimur, intelleginus etiam, cum alio lo quente id audimus. Quid est ergo tempus? Si nemo ex me quaerat, scio; si quaerenti explicare velim, nescio" [Augustine, Confessions II. 236-238].

59 Augustine, Confessions, 194; $c f$., "ego ascendens per animam meum ad te, qui despuper mihi manes, transibo et istam vim meam, quae memoria vocatur volens te attingere, unde attingi potes, et inhaerere tibi, unde inhaereri tibi potest" [Augustine, Confessions II, 122].

61) Augustine, Confessions, 208; cf., "ecce ubi sum! Flete mecum et pro me flete qui aliquid boni vobiscum intus agitis, unde facta procedumt" [Augustine, Confessions II, 168].

${ }^{61}$ Augustine, Confessions, 208; cf., "tu autem, domine deus meus, eaudi et resoice et vide et miserere et sana me, in cuius oculis mihi quaestio factus sum, et ipse est languor meus" [Augustine, Confessions II, 168].

${ }_{62}$ Caputo, Prayers and Tears, xvii.

63 Jacques Derrida and Geoffrey Bennington, Jacques/ Derrida,,translated by Geoffrey Bennington, "Circumfession,"(Chicago: Universoity of Chicago Press, 1993), 194.

64 Caputo, Prayers and Tears, xix.

${ }^{65}$ Augustine, Confessions, 221; $c f$., "Quando autem suffcio lingua calami enuntiare omnia hortamenta tua, et omnes terrores tuos et consolationes et gubernationes...? et si sufficio haec enuntiare ex ordine, caro mihi valent stillae temporum" [Augustine, Confessions II, 210]. 
66 Gabriel Marcel, Homo Viator, trans. by Emma Craufurd (Gloucester: Peter Smith, 1978), 28; "Tu te sens à l'etroit. Tu rêves d'évasion. Mais prends garde aux mirages. Pour t'évader, ne cours pas, ne te fuis pas: creuse plutôt cette place étroite qui t'est donnée; tu y trouveras Dieu et tout. Diell ne flotte pas sur ton horizon, il dort dans ton épaisseur: La vanité court, l'amour creuse. Si tu fuis hors de toi-même, ta prison courra avec toi et se rétrécira au vent de ta course; si tu t' enfonces en toi-même, elle s'évasera en paradis" [Gabriel Marcel, Viator, (Paris, Aubier, 1944), 35]. 